p-ISSN 0044-1600

e-ISSN 2392-3458

\section{Zagadnienia Ekonomiki Rolnej \\ Problems of Agricultural Economics}

$1(354) 2018,192-205$

DOI: $10.30858 /$ zer/89622

\title{
AGRICULTURAL MARKET - NEW ROLE OF DISTRIBUTION
}

\author{
ZENON POKOJSKI
}

\begin{abstract}
Agricultural market in Poland changed significantly after Poland's accession to the European Union. New entities emerged in the value chain of agricultural production, profitability of all links of the chain grew and the model of servicing agricultural producers underwent a major change. Entities such as Gmina Cooperatives "Samopomoc Chłopska” or Spółdzielnie Kółek Rolniczych (Farmers' Cooperative Associations) that were vital for distribution of means for agricultural production until 1989 - today are almost insignificant. Their role was taken over by private companies that very often started their activity on the grounds of property of bankrupt rural cooperatives.

Changes on the market of means for agricultural production in Poland proceeded differently to those in other countries of the Central and Eastern Europe. The main reason for this was different structure of farms - the key customers of the market, their legal, economic and social status. In the Czech Republic, Slovakia or Bulgaria there was much fewer very small private agricultural entrepreneurs. Whereas the distribution channels in Western Europe were formed by several decades of free market economy.

The model of distribution in Poland continues to evolve adjusting its offer to the dynamics of changes of their customers. Participants of agricultural market seek new possibilities to create and capture value, i.e. the highest margins in the chain of companies participating in manufacturing and supplying products to the final customer. The strongest ones try vertical and horizontal integration as well as different forms of partnership to shorten the distribution channels and take over as much value added as possible in the entire chain.
\end{abstract}

Keywords: agricultural market, distribution channel, distributer, agricultural advisory.

JEL codes: Q13, L11, L81.

Dr Zenon Pokojski, Uniwersytet Marii Curie-Skłodowskiej w Lublinie, Wydział Ekonomiczny, Laboratorium Praktyki Biznesu; pl. Marii Skłodowskiej-Curie 5, 20-031 Lublin (zenon.pokojski@umcs.pl). 


\section{Introduction}

The functioning of the agricultural market in post-transition Poland has changed significantly. New entities emerged in the value chain of agricultural production, profitability increased at all links of that chain, and the model of services for agricultural producers radically changed. Agri-food exports increased very dynamically from EUR 5.2 billion in 2004 to EUR 23.6 billion in 2015. The positive trade balance in this area has exceeded EUR 7.7 billion (Agencja Rynku Rolnego, 2016).

Entities that used to be important for the distribution of means of agricultural production until 1989, such as "Samopomoc Chłopska" Communal Cooperatives or Farmers' Cooperative Association, are much less important nowadays ${ }^{1}$. The changes were aggregated by the Act on changes to organisation and activities of cooperatives, which ordered all union centres to be disbanded (Act, 1990). Independent rural cooperatives were left on their own and had to face the emerging competition. Their role was taken over by private businesses, which often started their operations using the assets of the declining rural cooperatives.

A breakthrough moment for the dynamic development of companies offering means of production for agriculture was Poland's accession to the European Union and implementation of agricultural support programmes. Farmers benefited the most from the integration, but they also borne much higher costs of the transition and encountered incomparably more severe problems when confronted with free market mechanisms. This also was the case of distribution businesses that supplied farmers with means of production, and thus took part in changes to agriculture, in a way indirectly benefiting from the EU funds. Distributors in particular change the profile of their activities by extending their offer as a response to growing demand from end customers whose purchasing power increased (Michalski, 2003) ${ }^{2}$. The supplier of means of agricultural production become an important element of the Polish agricultural market organisation. Its new role was, on the one hand, determined by search for producers (e.g. of fertilizers, plant protection agents or agricultural machines and equipment), new distribution formula for their product and, on the other, demands from agricultural entrepreneurs who expected more complete, professional forms of cooperation with suppliers.

The breakthrough moment for businesses supplying means of production for agriculture was Poland's accession to the European Union. Polish rural areas and agriculture received 1/3 of the transfers from the EU budget. In 2004-2013, Poland received from that budget, under various Common Agricultural Policy instruments,

\footnotetext{
${ }^{1}$ At present, the "Samopomoc Chłopska" National Union of Cooperatives consists of about 964 cooperatives, while the National Union of Farmers' Cooperative Association comprises about 700 cooperatives.

${ }^{2}$ For the sake of orderliness in definitions, distribution, distribution channels, logistics are used in the sense proposed by Michalski (2003). In the objective and structural sense, logistics refers to an integrated structure of commodity flow and the related information flow. From the microeconomic perspective, distribution is a process of sales and supplies of products from a specific firm to the end customers. Distribution channel is a group of mutually interrelated firms, institutions and agencies that direct the product flow from producers to customers and facilitate it. The terms distributor and supplier of means of agricultural production and agricultural supply distributor are used interchangeably.
} 
EUR 29.4 billion (Nurzyńska and Poczta (ed.), 2014). The income situation of rural residents improved greatly ${ }^{3}$. The money was allocated e.g. to the development of processing industry, organisation of agricultural producer groups, environmental protection initiatives, improvement of infrastructure in communes, stimulation of local population's activity.

The Polish market of agricultural supplies was regarded as relatively poorly developed compared to markets in other European countries, such as Germany, France, the United Kingdom, the Netherlands, or Belgium (Cioch and Kłosowska, 2009). It was characterised by a small number of players whose strategy was based primarily on price competition. This situation, however, started to change rapidly after Poland's accession to the European Union. The number of players started to dwindle, distributors started to take the role of wholesalers and retailers.

The aim of this paper is to analyse the changes to distribution channels of agricultural means of production that have occurred since the change of Poland's government system, their function and importance for the development of the agricultural market. The author presents distribution in the context of its place and role in the value chain and discusses new phenomena aimed at building competitive advantage of entities in the distribution market.

The analysis of the distribution market in agriculture was prepared based on analysis of data from 2015 reports by TNS Polska and Ibris and the author's observations as the vice-president of the Board at Grupa Azoty Puławy supervising the area in question. As of yet, there are no available studies on the issue, which is surprising because the agricultural market has significantly changed over recent years.

\section{Distribution as an element of the value chain}

Global leaders see distribution as the key factor of market success. They arrange their value chain links and integrate distribution particularly strongly (Dawson, 2014). These processes accelerate at times of economic crisis. This point can be best illustrated by actions taken by such fertiliser producers as Agrium and Yara. In the course of their search for new opportunities, these companies focused on lengthening and broadening the value chain (Porter, 2006) ${ }^{4}$. They particularly developed the logistics capability of their product and distribution in order to be closer to the end customer. To this end, Agrium took over assets of distribution companies in the 2000s, thus ensuring:

- access to storage space for solid and liquid fertilisers (over 300,000 tonnes) in various European ports;

- access to about 3,750 railway tank cars and road vehicles, some of which are designed specially to transport fertiliser products;

- warehouses near centres of high demand, which allows delivery time and cost reduction in the periods of high demand.

\footnotetext{
${ }^{3}$ It has to be admited, however, that differences between urban and rural areas that are unfavourable to the latter still exist. The available income per capita in rural areas was at about $80 \%$ of the national average for years.

${ }^{4}$ The method is described in the literature as value chain analysis, value chain or value chain model; it is a concept of an internal analysis of an organisation developed by Porter in the late 1970s.
} 
Moreover, as a response to customer requirements, Agrium decided e.g. to provide agricultural advice services (Agrium, 2010).

Regardless of the ongoing horizontal integration, Yara also took measures in the field of vertical integration covering logistics and distribution optimisation. The aim was to make distribution channels as short as possible. It established a joint venture together in Denmark with DLG and AgroDK under the name Ferti Supply, which took over all the logistical functions. Its task is to optimise purchases and logistics, including storing products as near to the end customer as possible.

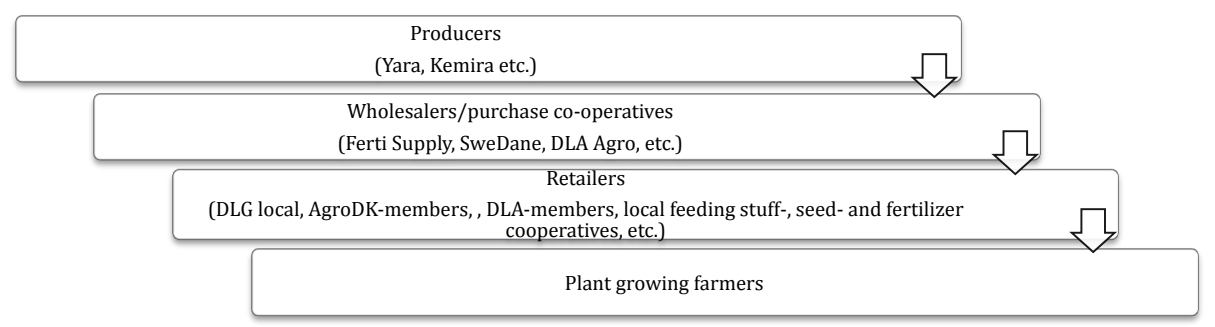

Fig. 1. Value chain.

Source: The creation of Ferti Supply (2006).

The value chain represents the manner of Ferti Supply's value building in three segments: production, wholesale, and retail, up to the moment it reaches the farmer. By strengthening relationships with wholesalers and distributors, the agricultural market leaders offer a wide range of value-added services for their customers. Distribution channels used in Europe differ between individual countries in their length and width. Longer and wider distribution channels are present in the Central and Eastern European countries, being in a way a legacy of the previous socioeconomic system. It should be admitted, however, that the distance is decreasing. In countries where free market economy has long traditions, distributors of means of agricultural production offer a broad range of products and services, including storage, transport, agricultural equipment rental or lease, and even risk management through price hedging instruments (Berger, 2015).

In their attempts at tightening the value chain through provision of more comprehensive services for their customers, they also offer advisory services, which in some cases, have become one of the more important sources of income.

When analysing the current trends in distribution present in individual Western European countries, it seems that they have developed the most in Germany, Belgium, and the Netherlands. The distributor takes the role of wholesaler and retailer, thus shortening the distribution channel. As a result of takeovers, the number of entities in the channel drops. Distributors put emphasis on the improvement in efficiency through value chain optimisation. They start to be difficult partners to work with for producers because they demand short delivery times, often exclusivity in their area of operation. 
As a response, the producers of means of agricultural production have started to seek opportunities for development through:

- horizontal integration (increasing their production market share, and thus improving their standing in negotiations),

- vertical integration (by developing own distribution channels),

- various forms of partnership with distributors.

Of course, the choice of strategy largely depends on the bargaining power of the producer $^{5}$.

\section{Change to the balance of forces on the Polish agricultural market}

The change to the workings of the market tends towards solutions used in developed markets in other European countries. Its participants are looking for ideas aimed at creating and capturing value, i.e. capturing the highest margins in the chains of businesses that take part in the production and delivery of the product to the end customer (Koźmiński, 2004). As stated by Koźmiński, the highest value is taken over by the strongest company in the chain. The trick is then to find an answer to the question: how to be the strongest link in the chain?

The first group interested in finding this answer consists of agricultural supply distributors. In 2004-2014, i.e. in the first decade of the Polish EU membership, the strongest of them increased their revenue several times. The leaders' revenues vastly exceed PLN 1 billion. It is worth noticing that Polish companies supplying means of agricultural production seek the opportunity to lengthen the value chain by trying to take over smaller producers of fertilisers or plant protection agents. This can be illustrated by the attempts at acquiring Gdańskie Zakłady Nawozów Fosforowych or Organika Sarzyna from the Ciech group.

The most important players in distribution on the agricultural market are private businesses. The five largest ones include: Chemirol, Osadkowski, Ampol-Merol, Agrolok, and Agrosimex. It should be observed that all the major distribution companies were established after the change of the Polish socio-economic system using the disused assets of the contemporary agricultural cooperatives or State Agricultural Farms. To a large extent, they owe the increase in their revenue to expansion of their offer for agricultural entrepreneurs. This offer is more and more often supported by proposals of courses, e.g. in the field of agronomy, and regular customers are offered the opportunity of bartering the supplied produce. All major players take advantage of work done by agricultural advisers in cooperation with farmers, thus strengthening relations with their customers. This diversity of services encourages farmers who expect comprehensive services from a single supplier.

\footnotetext{
${ }^{5}$ Boston Consulting Group, e.g., divided chemical production companies into three groups according to market conditions: low-cost players, regional leader, and global players. Each of the categories adopts a different strategy to build distribution channels in order to reach the end customer.
} 
Sales revenue of the largest Polish distributors in 2011-2016

\begin{tabular}{|c|c|c|c|c|}
\hline \multicolumn{5}{|l|}{1800000} \\
\hline \multicolumn{5}{|l|}{1500000} \\
\hline \multicolumn{5}{|l|}{1200000} \\
\hline 900000 & & & & \\
\hline 600000 & & 1 & & \\
\hline 300000 & & & & \\
\hline & & & & \\
\hline 0 & CHEMIROL & OSADKOWSKI & AGROLOK & AMPOL-MEROL \\
\hline$=2011$ & 1149295 & 1122538 & 966515 & 806107 \\
\hline$=2012$ & 1334878 & 1300720 & 1179925 & 1001934 \\
\hline \#2013 & 1375183 & 1235783 & 1296930 & 1053485 \\
\hline a 2014 & 1406538 & 1156217 & 1359909 & 1110840 \\
\hline 2015 & 1506794 & 1436996 & 1431630 & 1113782 \\
\hline 2016 & 1430398 & 1282546 & 1432311 & 1177418 \\
\hline
\end{tabular}

Source: own elaboration based on the "Lista 500" ranking by "Rzeczpospolita" for respective years.

In recent years, distribution companies greatly increased the value of their equity share. Though, the growth rate is not as high as in Western Europe, its oscillation around 10-20\% per annum indicates that the value of the distributors' assets is increasing. As a result, wealthy regional players emerge from the group, and their geographic reach is increasing.

Delivery of goods to a major agricultural customer is now a standard. What is becoming a source of competitive advantage is advice offered by the distribution company as a value added to the supplied goods. The aforementioned Chemirol company, established in 1990, currently employs 700 people. As many as 130 of them work to ensure good relations between the company and farmers. Another distribution company, Osadkowski, also established in 1990, has 374 employees, including 50 agricultural sales representatives. They are trained not only with regards to agricultural novelties but also in the field of customer service techniques. Yet another distribution company, Amper Merol, also focused on close cooperation with farmers. 65 out of 280 employees are agricultural sales representatives. But then, Hurtownia Rolnik supports activity of nearly 50 representatives through work of additional advisers according to the scheme below. 


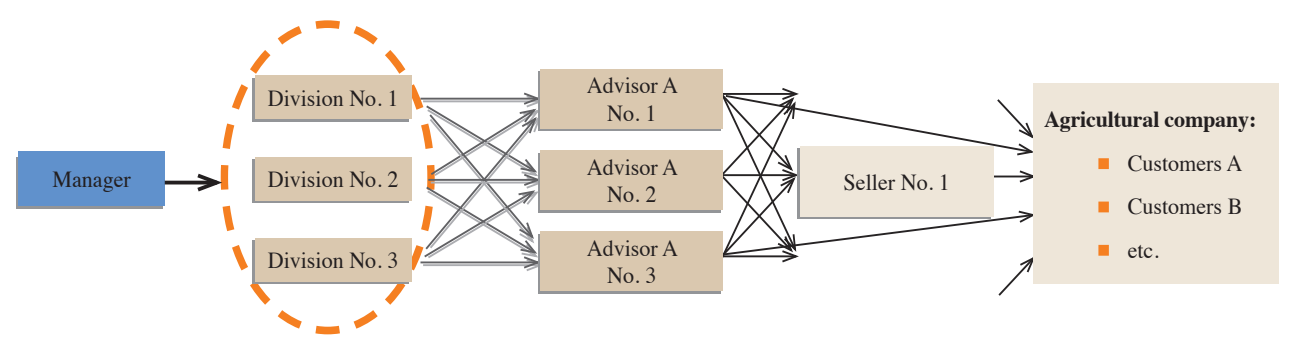

Divisions of a distribution company

Fig. 2. System of agricultural advice for farmers provided by a distribution company.

Source: prepared on the basis of materials from Hurtownia Środków do Produkcji Rolno Spożywczej Rolnik.

In this scheme, the role of adviser is performed by an agricultural specialist, while salespersons are agricultural sales specialists who contact agricultural entrepreneurs directly.

To summarise this train of thought, the expanding range of value-added services offered by distributors can be aggregated into certain blocs portraying the areas of interest:

- Distribution of goods from domestic and foreign producers for both animal and plant production using trade tools for keeping and acquiring customers (e.g. promotional goods, competitive prices, customer loyalty programmes, convenient forms of credit).

- Logistics - distribution companies often have several logistics bases at their disposal, which ensures quick delivery of means of production and transport of produce throughout the country. Some of them communicate with their customers online. Online platforms also provide them with an opportunity to promote their own products.

- Financial services - credits, loans, leasing, farm insurance, and assistance in obtaining funds from the EU aid programmes.

- Cooperation with the local community - local corporate social responsibility projects aimed at solving a village's problems with access to education, health care, cultural goods and supporting local institutions.

- Advisory services adjusted to the changing agricultural market based on competent agricultural advisers. Some distribution companies also issue professional journals that contain recommendations concerning plant cultivation and information on innovative production methods (Igras (ed.), 2014).

The second group interested in reinforcing their position in the chain of companies that participate in the production and delivery of goods to an agricultural producer, includes producers of means of agricultural production. Some of them started building their own distribution channels following the pattern set by large international corporations. This analysis will use the example of fertiliser producers, whose products account for about $30 \%$ of the value of the distribution market. 
The most active entity in this field is Grupa Azoty Puławy, and recently also the entire Grupa Azoty ${ }^{6}$ (Strategia Grupy Azoty, 2016). This group has large bargaining power due to the nearly $75 \%$ share of the Polish mineral fertiliser production market. The company at its disposal quays in Gdynia, Gdańsk and Police, bases for fertilisers in various locations around Poland, and it is also involved in providing additional training for agricultural sales representatives of the distributors ${ }^{7}$. Its strategy strongly emphasises building stable, efficient ties with their end customers by developing logistics and distribution systems for the group's products. The group puts increasing stress on the direct communication with agricultural entrepreneurs by supplying its products through the network of cooperating distributors. Thus, it builds the value of its relational capital (Dobiegała-Korona and Doligalski, 2010) ${ }^{8}$. The currently implemented distribution channel for products of Grupa Azoty is represented in the following Figure.

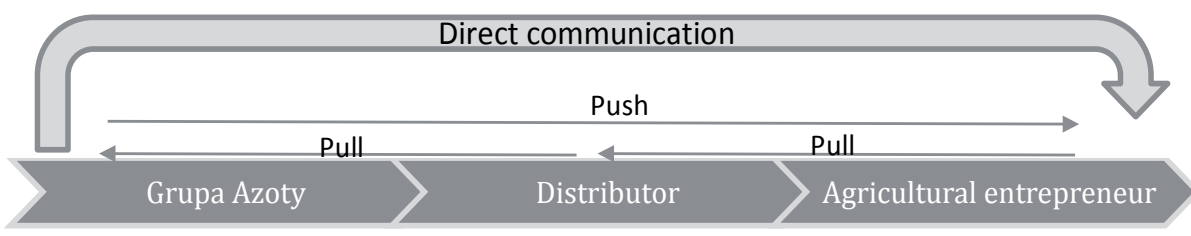

Fig. 3. Grupa Azoty Integration - distributor - farmer.

Source: based on materials from Grupa Azoty Puławy.

Push and pull strategies in the fertiliser distribution chain aim at active promotion of the product and its delivery through all the distribution chain links and pulling, i.e. ensuring direct impact of Grupa Azoty on end customers (farmers) to persuade them to buy the product.

\footnotetext{
${ }^{6}$ Grupa Azoty includes such entities as Grupa Azoty Puławy, Police, Tarnów and Kędzierzyn and Gdańskbased Fosfory and Siarkopol.

${ }^{7}$ Grupa Azoty Puławy and the Warsaw University of Life Sciences jointly organise postgraduate programmes for their regional representatives and employees - distributors working with farmers. The curriculum of the programme entitled "Trade in fertilisers and plant protection agents" was prepared in cooperation with the producer. Apart from the diploma, the graduates receive two certificates authorising them to trade in, prepare and apply plant protection agents intended for professional use.

${ }^{8}$ Relational capital, understood as the value of maintaining long-term, mutually beneficial relations with customers for the company. This capital is listed as a component of a company's intellectual capital.
} 
Table 2

Perception offertiliser producer brands ${ }^{a}$

\begin{tabular}{|c|c|c|c|c|c|c|c|c|c|}
\hline Factors & Puławy & Police & Kędzierzyn & Tarnów & Anwil & Yara & Fosfory & Luvena & Siarkopol \\
\hline $\begin{array}{l}\text { Offers high } \\
\text { product } \\
\text { quality }\end{array}$ & 8.2 & 8.0 & 7.7 & 7.5 & 7.8 & 7.4 & 7.5 & 7.4 & 7.2 \\
\hline $\begin{array}{l}\text { Fertilisers } \\
\text { from this } \\
\text { producer are } \\
\text { easily available }\end{array}$ & 8.2 & 8.0 & 7.8 & 7.7 & 7.9 & 7.3 & 7.4 & 7.7 & 7.3 \\
\hline $\begin{array}{l}\text { Fertilisers } \\
\text { have } \\
\text { attractive } \\
\text { price }\end{array}$ & 7.1 & 6.8 & 7.0 & 7.1 & 7.1 & 6.7 & 6.9 & 7.0 & 6.7 \\
\hline $\begin{array}{l}\text { I hear about } \\
\text { this producer } \\
\text { more often } \\
\text { than about } \\
\text { others }\end{array}$ & 8.0 & 7.6 & 7.5 & 7.5 & 7.6 & 7.1 & 6.7 & 7.2 & 6.6 \\
\hline $\begin{array}{l}\text { Recommended } \\
\text { by farmers } \\
\text { and } \\
\text { well-know }\end{array}$ & 7.8 & 7.6 & 7.4 & 7.4 & 7.6 & 7.0 & 6.9 & 7.3 & 6.9 \\
\hline $\begin{array}{l}\text { Products } \\
\text { are } \\
\text { trustworthy }\end{array}$ & 8.2 & 8.0 & 7.6 & 7.6 & 7.9 & 7.3 & 7.4 & 7.5 & 7.0 \\
\hline $\begin{array}{l}\text { Innovative/ } \\
\text { modern } \\
\text { brand }\end{array}$ & 8.0 & 7.7 & 7.6 & 7.6 & 7.8 & 7.5 & 7.3 & 7.3 & 6.8 \\
\hline $\begin{array}{l}\text { Products are } \\
\text { safe for crops }\end{array}$ & 8.2 & 7.9 & 7.7 & 7.6 & 7.9 & 7.4 & 7.7 & 7.6 & 7.2 \\
\hline $\begin{array}{l}\text { Supports } \\
\text { farmers } \\
\text { in farm } \\
\text { operation }\end{array}$ & 7.3 & 7.1 & 7.1 & 7.2 & 7.0 & 7.1 & 7.0 & 6.9 & 6.5 \\
\hline
\end{tabular}

${ }^{a}$ The evaluation is based on a $1-10$ scale, where 1 means that a statement does not fit the brand, and 10 that it suits the brand completely.

Source: TNS Polska (2015, p. 47).

The strategy for reaching out to the end customer through close cooperation with distributors has been effective so far, which is confirmed by surveys (TNS Polska, 2015). Noticeably, in the search for added value, Grupa Azoty in particular makes effort to build relations with end customers, or in other words, tries to manage the value of its customers. This group also has two distribution companies in its portfolio.

The third interested group consists of larger agricultural entrepreneurs or the so-called purchasing group, whose basic goal is to increase their bargaining power in the purchase of means of agricultural production. These groups more and more 
willingly undertake negotiations with producers of those goods and skip distributors in order to shorten the distribution channel. Thus, they follow solutions used in global corporations, which also undertake distribution activities by addressing their offer to smaller scale farmers. In this way, they intend to optimise their supply costs of means of agricultural production. Some of them have their own agricultural experts and also provide agricultural advice services. Therefore, the game is about dividing the added value of the big cake, which is the agricultural market.

In Poland, the regional diversity of the distribution market is growing. The phenomena discussed above are the most intense in the northern and western part of the country. This results from the fact that the agricultural businesses are larger and stronger economically. Eastern voivodships, on the other hand, are dominated by provision of goods and services to relatively small-scale farms operated by private farmers. As of now, the largest area agricultural holdings over 100 ha are located in four voivodships: Dolnośląskie, Warmińsko-Mazurskie, Wielkopolskie and Zachodniopomorskie (GUS, 2017). These are also voivodships where agriculture is $\mathrm{d}$ mineral fertiliser use is high, and cereal yield is good.

\section{Delivering added value to customers as a source of competitive advantage building}

Distributors seek opportunities to deliver added value increasing their relational capital. Advisory services have become one of them. It has become an element of the distributor's business model aimed at supporting customer services ${ }^{9}$. Some distributors are developing these services in a very broad scope and do not include only informational or educational functions, but also innovation and implementation (Brodnicki and Chyłek, 1999). Private distributors willingly take advantage of new forms of training, such as workshop, coaching or demonstrations. The last option has become a standard during the "Dni Pola" event organised by the companies in question. Persons speaking as experts at those events are company representatives and academic teachers ${ }^{10}$. It should be stressed that the level of these professional services, which benefit from the newest scientific and practical achievements not only Polish but also international, is continuously increasing. The competitive pressure forces such companies to continuously educate their experts and improve their qualifications. Distributors have knowledge e.g. of the products bought by their customers and the frequency of such purchases. This allows the companies to manage their portfolios.

The most cited objection to advisory services offered by the distributors is lack of objectivity - "the purpose is to sell one's products". It should be noted, however, that a customer using advisory services is not helpless. As shown by surveys, a vast major-

\footnotetext{
${ }^{9}$ Some of them established separate companies providing such services, e.g. the Osadkowski company established the Agrainvest consulting firm.

${ }^{10}$ For example, the lecture delivered by an academic staff member of the Poznan University of Life Sciences during "Meetings in demonstration fields of oilseed rape" organised by the Teamagro company in June 2013 in the Zamość region was attended by nearly 700 farmers. In the following years, advisory services gained even more popularity.
} 
ity of them checks various offers in the press, in catalogues or on the Internet prior to making a decision on purchase (TNS Polska, 2015; Ibris, 2015). Secondly, due to such strong competition, suppliers of means of agricultural production make effort to develop good long-term relations with their customers, so they are not interested in one-off transactions that are beneficial only to them. Thirdly, suppliers are more and more often forced by their customers to deliver products that the latter trust. This process is supported by direct communication between agricultural supply producers and agricultural entrepreneurs. Fourthly, the advisory services in the sector are sensitive to all kinds of innovative solutions, particularly those related to modern customer communication tools. Fifthly, in the area related to agricultural advice, distributors are subjected to the pressure on the result while building their relational capital. None of the partners is satisfied with a single successful transaction (Pokojski, 2014).

Distributors are also involved in organising financing for activities undertaken by their customers - agricultural entrepreneurs. Over the years, two dominant forms of credit have developed in agriculture:

- $\quad$ supplier credit - trade credit - in the form of sales on deferred payment terms used for the purchase of plant protection agents, fertilisers, or seed material;

- loan from credit institutions - i.e. banks or leasing companies offering bank credit, loans or leasing - used for the purchase of agricultural equipment or land.

Observation of the leading suppliers of means of agricultural production on the Polish market leads to the conclusion that trade credit has become the most attractive form of crediting. Distributors managed to reduce red tape involved in the process of approving payment on deferred terms without resignation from assessment of the customer's creditworthiness or securing of payment. They have developed their own trade credit rules as an integral part of their trade offer. There might be an impression that financial institutions are much slower in implementing such changes in their approach to agricultural credit.

At the point where agricultural entrepreneurs and large agri-food sector entities meet, a new financial offer of production connections in agriculture is developing. This solution consists in provision of working capital or investment financing on preferential terms set out in a framework agreement between a bank and a large agri-food sector entity, in most cases a distributor. This entity, often referred to as the connection leader, directly cooperates with the financed agricultural producers. From the connection leader's perspective, the advantage of this solution is the construction of good relations with cooperating agricultural entities and increased transparency of transaction settlements due to support offered by the bank, while for agricultural producers, this means lower cost of financing. Furthermore, the connection leader may, as part of the cooperation with the bank, offer a customer a discount on offered products, and even participate in the cost of financing. Due to the cooperation with the connection leader, the bank may more easily carry out joint marketing activities and reach potential customers with its offer. The connection leader has the knowledge of the customers that in principle is not available to the banks.

A Polish farmer most often acquires knowledge necessary to operate the farm from "opinion leaders" (46\%), Internet (40\%), and then TV programmes on agricul- 
ture (37\%) and agricultural press (29\%). Agricultural Advice Centres were indicated by $7 \%$ of the respondents. Noticeably, the survey shows that $10 \%$ of the respondents pointed to demonstrations and events and $8 \%$ to training sessions organised by producers or suppliers of means of agricultural production as a source of knowledge. Here, regional diversity is also great. In Kujawsko-Pomorskie Voivodship, 77\% of farms acquire agricultural knowledge from the press, while in Świętokrzyskie, Małopolskie and Podkarpackie this pertains only to 6\% (TNS Polska, 2015). The survey results show major changes to communication channels used by farmers for acquiring knowledge of farming operations. Suppliers of means of agricultural production also had to adjust to the situation.

There is another evident fact on the Polish agricultural market - as many as $77 \%$ of farms has access to the Internet, and $37 \%$ use it to look for knowledge on business operations or business decision making (Ibris, 2015, p. 5). Internet as a method of information exchange is a new communication channel between the sellers and the customers. Both producers and distributors quickly responded to the opportunities it provides, so they try to use it to build relations with their customers. For instance, Grupa Azoty has deployed an e-commerce solution, a tool whose purpose is not only to facilitate transactions, but also to convey knowledge on the properties of offered fertilisers, inform the customer on delivery status or pending complaint procedures.

\section{Conclusions}

The distribution model in Poland is still evolving adjusting its offer to the dynamics of change in its customers. Participants of the agricultural market seeking new opportunities for creating and capturing value, i.e. capturing the highest margins in the chain of businesses that take part in the production and delivery of the product to the end customer. The trick is then to find the answer to the question: how to be the strongest link in the chain?

Distribution companies in Poland very quickly professionalise their customer handling skills. The companies are more and more organisationally efficient and economically strong, they also use modern ICT tools. A period of particular growth was the time of Poland's accession to the European Union. Today, distribution companies more and more willingly offer advisory services and services related to organising financing for their customers' activities as a value added to the offer of delivered products.

The distribution of means of agricultural production is highly competitive in Poland. We can observe both vertical and horizontal integration and also cooperation between distributors and producers aimed at improving efficiency and effectiveness of measures aimed at reaching the customer. The dynamics of further development will to a large extent depend on the customer service quality in the agricultural market, the capacity to find new sources of financing, the capability to transfer knowledge and innovation from academic and research institutions to deployment in an agricultural business. In most general terms, the distribution will develop at the same rate that it will be able to support value building of agricultural enterprises. 


\section{References}

ABM (2012). Raport z badań. Opis sytuacji ZAP na rynku polskim. Puławy-Warszawa, pp. 292-296.

Act of 20 January 1990 on changes to organisation and activities of cooperatives. Dz.U. 1990, No. 6, item 36.

Agencja Rynku Rolnego, Biuro Analiz i Programowania (2016). Polski handel zagraniczny towarami rolno-spożywczymi w 2015 r. Retrieved from: http://www.arr.gov.pl/data/00167/pol_ handel_zagraniczny_2015.pdf (access date: 18.12.2016).

Agrium (2010). Growing Across the Value Chain. Retrieved from: http://www.agrium.com/en/ what-we-do/history (access date: 18.04.2017).

Berger, R. (2015). Supply chain management \& Logistics, Functional know-how, Expertise. Roland Berger.

Brodnicki, Z., Chyłek, E.K. (1999). Doradztwo w agrobiznesie. Olsztyn: Wyd. ART, p. 21.

Cioch, G., Kłosowska, D. (2009). Rynek nawozowy - dystrybucja rządzi. Nowy Przemyst, nr 9/2009, pp. 28-31.

Dawson, J. (2014), Commercial Distribution in Europe. Nowy Jork: Routledge Revivals.

Dobiegała-Korona, B., Doligalski, T. (2010). Zarzadzanie wartościa klienta. Pomiar i strategie. Warszawa: Wydawnictwo Poltext.

GUS (2017). Rocznik Statystyczny Rolnictwa 2016. Warszawa: GUS.

GUS (2014a). Środki Produkcji w Rolnictwie w roku gospodarczym 2012/2013. Warszawa: GUS.

GUS (2014b). Społeczeństwo Informacyjne w Polsce z lat 2009-2013. Warszawa: GUS.

IBRiS (2015). Przedsiębiorcy rolni o obecnej sytuacji w rolnictwie. Raport z badań. Warszawa: IBRiS.

Igras, J. (ed.). (2014). 25 lat polskiego rolnictwa. Bezpieczeństwo żywnościowe w Europie. Raport. Puławy: Centrum Kompetencji Puławy.

Koźmiński, A. (2004). Zarządzanie w warunkach niepewności. Warszawa: Wydawnictwo Naukowe PWN.

Krajowa Rada Spółdzielcza. Historia, Branże Spółdzielcze. Retrieved from: http://www.krs.org. pl/index.php (access date: 18.12.2016).

Lista 500 największych firm Rzeczpospolitej. Retrieved from: http://www.rp/pl (access date: 18.12.2016).

Michalski, E. (2003). Marketing. Podręcznik akademicki. Warszawa: Wydawnictwo Naukowe PWN.

Nurzyńska, I., Poczta, W. (ed.) (2014). Raport o stanie wsi. Polska wieś 2014. Synteza, Warszawa: Wydawnictwo Naukowe Scholar.

Pokojski Z. (2014). Doradztwo rolnicze we wdrażaniu innowacji w polskim sektorze żywnościowym. Warszawa: Biuro Analiz Sejmowych. Retrieved from: http://www.senat.gov.pl/gfx/senat/userfiles/_public/k8/.../2014/.../1096-14a_pokojski.pdf (access date: 11.02.2017).

Porter, M.E. (2006). How competitive forces shape strategy. Strategic Planning: Readings, Juta and Company Ltd.

Strategia Grupy Azoty 2013-2020. Retrieved from: http:// www.grupaazoty.pl (access date: 18.12.2016).

The creation of Ferti Supply (2006). Retrieved from: https://www.kfst.dk/ (access date: 18.04.2017).

TNS Polska (2015). Znajomość marek nawozów - monitoring zmian i analiza działań marketingowych. Raport z badań. Warszawa. 


\title{
RYNEK ROLNY - DYSTRYBUCJA W NOWEJ ROLI
}

\begin{abstract}
Abstrakt
Rynek rolny w Polsce znacznie się zmienit po przystapieniu do Unii Europejskiej. Pojawiły się nowe podmioty w łańcuchu wartości produkcji rolnej, zwiększyła się dochodowość we wszystkich ogniwach tego łańcucha, diametralnie zmienił się model obsługi producentów rolnych. Ważne dla dystrybucji środków do produkcji rolnej do 1989 roku podmioty, takie jak np. Gminne Spółdzielnie „Samopomoc Chłopska” czy Spółdzielnie Kółek Rolniczych, maja dzisiaj marginalne znaczenie. Ich role przejęty firmy prywatne, które bardzo często działalność rozpoczynały na bazie majątku upadającej spółdzielczości wiejskiej.

Zmiany w dystrybucji środków do produkcji rolnej w Polsce przebiegały inaczej niż w innych krajach Europy Środkowo-Wschodniej. Podstawowym powodem była inna struktura gospodarstw rolnych - głównych klientów tego ryn$k u$, ich status prawny, ekonomiczny $i$ społeczny. W Czechach, na Słowacji czy w Bułgarii nie było tak wielu, tak małych prywatnych przedsiębiorców rolnych. Z kolei kanały dystrybucji w krajach Europy Zachodniej zostały ukształtowane przez dziesiatki lat gospodarki wolnorynkowej.

Model dystrybucji w Polsce wciąz ewoluuje, dostosowujac swoja oferte do dynamiki zmian swoich klientów. Uczestnicy rynku rolnego poszukuja nowych możliwości tworzenia i przechwytywania wartości, czyli przechwytywania najwyższych marż w łańcuchu firm, które uczestnicza $w$ wytworzeniu i dostarczeniu produktu klientowi finalnemu. Najsilniejsi próbuja integracji pionowej i poziomej, jak również różnych formut partnerstwa w celu skrócenia kanału dystrybucji i przejęcia jak największej wartości dodanej w całym łańcuchu.
\end{abstract}

Słowa kluczowe: rynek rolny, kanał dystrybucji, dystrybutor, doradztwo rolne.

Accepted for print: 27.04.2018.

Unless stated otherwise all the materials on the website are available under the Creative Commons Attribution 4.0 International license.

Some rights reserved to the Institute of Agricultural and Food Economics - National Research Institute.

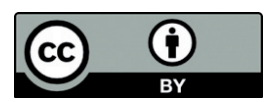

